\title{
ANALISIS KESALAHAN BAHASA PADA PERCAKAPAN BAHASA ARAB MAHASISWA JURUSAN PENDIDIKAN BAHASA ARAB (PBA) INSTITUT AGAMA ISLAM NEGERI (IAIN) METRO TAHUN AKADEMIK 2017/2018
}

\author{
Walfajri \\ Institut Agama Islam Negeri (IAIN) Metro \\ Jl. Ki Hajar Dewantara 15A Iring Mulyo Kota Metro \\ walfajri2018@gmail.com
}

\begin{abstract}
This study aimed at classifying the kinds of errors in Arabic conversations of students majoring in Arabic at the State Islamic Institute of Metro in Academic Year 2017/2018, describing the frequency of the language errors, and explaining the factors that caused the language error. The data were collected through observation, field notes, and tape recording. The results showed that errors in Arabic conversations of students majoring in Arabic at the State Islamic Institute of Metro in Academic Year 2017/2018 can be classified in three kinds of languages errors, namely: (1) the pronunciation errors, (2) the morphology errors, and (3) the syntax errors. On the kind of pronunciation errors, the highest frequency of errors occurred at pronunciation of / ض/, / ث/, /, and $/ \dot{j}$. On the kind of morphology errors, the highest frequency of errors occurred at tashrif fi'il madhiy and tashrif fi'il mudhari'. On the kind of syntax errors, the highest frequency of errors occurred at the structure of mudhaf-mudhaf ilaih, na'at-man'ut, and jar-majrur. The factors that caused the pronunciation errors can be categorized as the inter-language errors. While the factors that caused morphology errors and syntax errors can be categorized as the intra-lingual errors.
\end{abstract}

Keywords: Language errors, inter-language errors, intra-language errors.

\begin{abstract}
Abstrak
Penelitian ini bertujuan untuk mengklasifikasikan jenis-jenis kesalahan dalam percakapan bahasa Arab mahasiswa Jurusan Bahasa Arab IAIN Metro Tahun Akademik 2017/2018, mendeskripsikan frekuensi kesalahan bahasa, dan menjelaskan faktor-fakor penyebab kesalahan bahasa tersebut. Data dikumpulkan melalui observasi, catatan lapangan dan rekaman. Hasil penelitian menunjukkan bahwa kesalahan dalam percakapan bahasa Arab mahasiswa Jurusan Bahasa Arab IAIN Metro Tahun Akademik 2017/2018 dapat diklasifikasikan ke dalam tiga jenis kesalahan, yaitu: (1) kesalahan pengucapan bunyi bahasa, (2) kesalahan morfologi (sharaf), dan (3) kesalahan tata bahasa (nahwu). Pada kesalahan pengucapan bunyi bahasa, frekuensi kesalahan tertinggi terjadi pada pengucapan bunyi / ا /, / I/, Pada kesalahan morfologi (sharaf), frekuensi kesalahan tertinggi terjadi pada tashrif fi'il madhiy dan tashrif fi'il mudhari'. Pada kesalahan tatabahasa (nahwu), frekuensi kesalahan tertinggi terjadi pada struktur mudhaf-mudhaf ilaih, na'at-man'ut, dan jar-majrur. Adapun faktor penyebab terjadinya kesalahan pengucapan bunyi dikategorikan sebagai kesalahan antar-bahasa. Sedangkan faktor penyebab terjadinya kesalahan morfologi (sharaf) dan tata bahasa (nahwu) dikategorikan sebagai kesalahan intra-bahasa.
\end{abstract}

Kata kunci: Kesalahan bahasa, kesalahan antar-bahasa, kesalahan intra-bahasa. 


\section{Pendahuluan}

Studi mengenai kesalahan bahasa dalam kaitannya dengan pembelajaran bahasa Arab sebagai bahasa asing sangat fungsional. Melalui pengkajian kesalahan itu, ragam kesalahan, klasifikasi kesalahan, frekuensi terjadinya kesalahan, dan faktor-faktor yang menyebabkan terjadinya kesalahan dapat diungkap. Hasil dari studi itu dapat dijadikan umpan balik dalam penyempurnaan atau perbaikan pembelajaran bahasa Arab.

Dari pengalaman selama sebelas tahun mengajar mata kuliah Maharah alKalam pada mahasiswa Jurusan Pendidikan Bahasa Arab IAIN Metro, peneliti sering mendapatkan kesalahan bahasa dalam praktek percakapan bahasa Arab mereka. Di antara kesalahan itu, terdapat ketidak-tepatan dalam pengucapan fonem atau bunyi huruf-huruf Arab dan pengucapan harakat qashirah dan thawilah, kesalahan dalam penerapan tashrif fi 'il madhi dan mudhari', ketidaksesuaian antara mubtada' dan khabar, fi 'il dan fail, 'adad dan ma'dud, kesalahan dalam penerapan kaidah tarkib idhafiy dan tarkib washfiy, dan lain-lain.

Namun demikian, selama ini belum dilakukan analisis secara serius dan mendalam terhadap kesalahan bahasa dalam percakapan bahasa Arab mahasiswa tersebut, sehingga tidak dapat diketahui klasifikasi jenis kesalahan bahasa, frekuensi terjadinya kesalahan, dan faktorfaktor yang menyebabkan terjadinya kesalahan terebut. Oleh karena itu, penelitian tentang analisis kesalahan bahasa pada percakapan bahasa Arab mahasiswa Jurusan Pendidikan Bahasa Arab IAIN Metro Tahun Akademik 2017/2018 ini perlu dilakukan.

Penelitian ini difokuskan pada permasalahan analisis kesalahan bahasa pada percakapan bahasa Arab mahasiswa Jurusan Pendidikan Bahasa Arab IAIN Metro Tahun Akademik 2017/2018 menurut taksonomi kategori linguistik, yang mencakup kesalahan fonologi (ucapan), kesalahan morfologi (sharaf), kesalahan sintaksis (nahwu), dan faktor-faktor yang menyebabkan terjadinya kesalahan-kesalahan bahasa tersebut

Penelitian ini ingin menjawab pertanyaan: (1) bagaimanakah klasifikasi jenis-jenis kesalahan bahasa pada percakapan bahasa Arab mahasiswa Jurusan Pendidikan Bahasa Arab semester III Tahun Akademik 2017/2018?, (2) bagaimanakah frekuensi terjadinya kesalahan bahasa tersebut, dan (3) apa sajakah faktor-faktor yang menyebabkan terjadinya kesalahan bahasa tersebut?

Sejalan dengan pertanyaan penelitian di atas, penelitian ini bertujuan untuk mengklasifikasikan jenis-jenis kesalahan bahasa pada percakapan bahasa Arab mahasiswa Jurusan Pendidikan Bahasa Arab semester III Tahun Akademik 2017/2018, mendeskripsikan frekuensi terjadinya kesalahan bahasa tersebut, dan menjelaskan 
faktor-faktor yang menyebabkan terjadinya kesalahan bahasa tersebut.

\section{Kajian Teori}

\section{Pengertian Analisis Kesalahan Bahasa}

Dulay (1982) mengungkapkan bahwa kesalahan bahasa merupakan bagian-bagian konversasi atau komposisi yang menyimpang dari norma baku atau norma terpilih dari performansi bahasa orang dewasa. ${ }^{1}$ Sedangkan analisis kesalahan bahasa adalah suatu prosedur kerja yang biasa digunakan oleh para peneliti dan guru bahasa, yang meliputi pengumpulan sampel, pengidentifikasian kesalahan yang terdapat dalam sampel, penejelasan kesalahan tersebut, pengklasifikasian kesalahan itu berdasarkan penyebabnya, serta pengevaluasian atau penilaian taraf keseriusan kesalahan itu. $^{2}$

\section{Langkah-Langkah \\ Kesalahan Bahasa}

Analisis

Sebagai prosedur kerja, analisis kesalahan bahasa mempunyai langkahlangkah tertentu. Langkah-langkah inilah yang dimaksud dengan "metodologi" analisis kesalahan bahasa. Ada dua orang

1 H. Dulay [et al], Language Two. (Oxford: Oxford University Press, 1982), h. 277.

2 R. Ellis, Understanding Second Language Acquisition. (Oxford: Oxford University Press, 1987), h. 296. pakar yang telah mengemukakan metodologi analisis kesalahan bahasa, yaitu Sridhar (1985) dan Ellis (1986). Menurut Sridhar (1985), dalam Tarigan dan Tarigan (1990), ${ }^{3}$ ada enam langkah analisis kesalahan bahasa, yaitu:

a. Mengumpulkan data

b. Mengidentifikasi kesalahan

c. Mengklasifikasi kesalahan

d. Menjelaskan frekuensi kesalahan

e. Mengidentifikasi daerah

kesukaran/kesalahan

f. Mengoreksi kesalahan

Sedangkan menurut Ellis (1986), dalam Tarigan dan Tarigan (1990), ${ }^{4}$ ada lima langkah analisis kesalahan bahasa, yaitu:

a. Mengumpulkan sampel kesalahan

b. Mengidentifikasi kesalahan

c. Menjelaskan kesalahan

d. Mengklasifikasi kesalahan

e. Mengevaluasi kesalahan

Bila kedua metodologi analisis kesalahan bahasa itu dibandingkan, maka jelas terlihat adanya kemiripan. Perbedaannya bisa dikatakan hanya pada segi perbaikan atau koreksi kesalahan.

Selanjutnya, berdasarkan tela'ah terhadap kedua metodologi analisis kesalahan bahasa di atas, Tarigan dan Tarigan (1990) ${ }^{5}$ melakukan modifikasi

\section{${ }^{3}$ Henry Guntur Tarigan dan Djago Tarigan,} Pengejaran Analisis Kesalahan Berbahasa, (Bandung: Angkasa, 1990), h. 70.

\footnotetext{
${ }^{4}$ Ibid.

${ }^{5}$ Ibid., h. 71.
} 
dengan menyusun langkah-langkah analisis kesalahan bahasa sebagai berikut:

a. Mengumpulkan data: berupa kesalahan bahasa yang dibuat oleh siswa, misalnya hasil ujian, karangan, atau percakapan.

b. Mengidentifikasi dan mengklasifikasi kesalahan: mengenali dan memilah-milah kesalahan berdasarkan kategori kebahasaan, misalnya kesalahan pelafalan, pembentukkan kata, penggabungan kata, dan penyusunan kalimat.

c. Memperingkat kesalahan: mengurutkan kesalahan berdasarkan frekuensi atau keseringannya.

d. Menjelaskan kesalahan: mengambarkan letak kesalahan, penyebab kesalahan, dan memberi contoh yang benar.

e. Memprediksi butir kebahasaan yang rawan kesalahan: meramalkan tataran bahasa yang dipelajari yang potensial mendatangkan kesalahan.

f. Mengoreksi kesalahan: memperbaiki dan bila dapat menghilangkan kesalahan melalui penyusunan bahan ajar yang tepat, buku pegangan yang baik, dan teknik pembelajaran yang serasi.

\section{Faktor-Faktor}

Penyebab Kesalahan Bahasa
Secara umum telah diketahui bahwa identifikasi dan analisis interpretasi antara bahasa-bahasa yang saling kontak, secara tradisional merupakan aspek pokok telaah kedwibahasaan. Dalam kontak antara bahasabahasa itu terjadi saling pengaruh dan penyimpangan yang menyebabkan kesalahan. Secara garis besar, kesalahan bahasa dapat dibedakan atas:

a. Kesalahan antarbahasa (interlanguage errors), yaitu kesalahan yang disebabkan oleh interferensi bahasa ibu si pelajar terhadap bahasa kedua (B2) atau bahasa asing yang dipelajari.

b. Kesalahan intrabahasa (intralingual errors), yaitu kesalahan yang merefleksikan ciri-ciri umum kaidah yang dipelajari seperti kesalahan generalisasi, aplikasi yang tidak sempurna terhadap kaidah bahasa, dan kegagalan mempelajari kondisi-kondisi penerapan kaidah.

Senada dengan ciri-ciri umum kesalahan di atas, Fisiak $(1985)^{6}$ mengklasifikasikan penyebab kesalahan intrabahasa ini ke dalam empat macam, yaitu:

a. Penyamarataan berlebihan (overgeneralization), yaitu kesalahan yang disebabkan oleh penyamarataan

${ }^{6}$ Jack Fisiak [ed]. Contrastive Linguistics and Language Teacher, (New York: Pergamon Press, 1985), h. 174. 
kaidah-kaidah bahasa sasaran pada konteks-konteks yang tidak tepat.

b. Ketidaktahuan akan pembatasan kaidah (ignorance of rule restrictions), yaitu kesalahan yang disebabkan oleh ketidaktahuan akan pembatasan kaidah-kaidah bahasa sasaran, atau penerapan kaidahkaidah bahasa terhadap kontekskonteks yang tidak menerima penerapan tersebut.

c. Penerapan kaidah yang tidak sempurna (incomplete application of rules), yaitu kesalahan yang disebabkan oleh terjadinya strukturstruktur yang penyimpangannya menggambarkan taraf perkembangan kaidah-kaidah yang diperlukan untuk menghasilkan ucapan atau ujaran yang dapat diterima.

d. Salah menghipotesiskan konsep (false concepts hypothesized), yaitu kesalahan yang disebabkan oleh pemahaman yang salah terhadap pembedaan-pembedaan di dalam bahasa sasaran.

\section{HASIL PENELITIAN DAN PEMBAHASAN}

Dari hasil rekaman dan transkripsi hasil rekaman percakapan bahasa Arab mahasiswa Semester III Jurusan Pendidikan bahasa Arab IAIN Metro
Tahun Akademik 2017/2018 dalam aktivitas perkuliahan Maharah al-Kalam 2, diperoleh data tentang kesalahan bahasa yang dapat diklasifikasikan kedalam tiga kategori, yaitu:

(1) kesalahan pengucapan bunyi, kesalahan morfologi (sharaf), dan (3) kesalahan sintaksis (nahwu). Data mengenai ketiga kategori kesalahan bahasa tersebut dipaparkan sebagai berikut:

\section{Kesalahan Pengucapan Bunyi (Fonem)}

Dalam penelitian ini, kesalahan bahasa pada tataran pengucapan bunyi dianalisis berdasarkan ketepatan makhraj-nya. Di dalam bahasa Arab terdapat 28 bunyi (fonem), 16 fonem di antaranya memiliki kesamaan dengan bunyi (fonem) bahasa Indonesia, yaitu:

$$
\begin{aligned}
& \text { /ب/، /ت/، /ج/، /د/، /ر/، / ز/، /س/، /ف/، /צ/، /J/، } \\
& \text { /م/، /ن/، /و/، /هـ/، /\&/، /ي/. }
\end{aligned}
$$

Mahasiswa pada umumnya tidak mengalami kesulitan sama sekali dalam mengucapkan 16 fonem bahasa Arab di atas karena adanya kemiripan antara 16 fonem bahasa Arab itu dengan fonem bahasa Indonesia.

Adapun 12 fonem di antaranya memiliki perbedaan dengan bunyi (fonem) bahasa Indonesia. Dengan kata lain, 12 fonem di antaranya tidak terdapat bunyi fonem yang mirip atau sama dalam bahasa Indonesia, yaitu:

$$
\text { /غ/ث/، /ح/، /خ/، /ذ/، /ش/، /ص/، /ض/، /ط/، /ظ/، /ع/، }
$$

Mahasiswa pada umumnya mengalami 
kesulitan dalam mengucapkan 12 fonem bahasa Arab di atas karena tidak terdapat bandingannya dalam fonem bahasa Indonesia. Oleh karena itu, analisis kesalahan bahasa dalam penelitian ini difokuskan pada pengucapan 12 bunyi (fonem) bahasa Arab ini.

Adapun paparan data mengenai kesalahan pengucapan 12 bunyi (fonem) bahasa Arab tersebut dapat dilihat pada tabel berikut:

Tabel 1: Kesalahan Pengucapan Bunyi

\begin{tabular}{|c|c|c|c|c|c|c|}
\hline No. & $\begin{array}{l}\text { Bunyi } \\
\text { (Fone } \\
\text { m) }\end{array}$ & $\begin{array}{l}\text { Frekue } \\
\text { nsi } \\
\text { Penguc } \\
\text { apan }\end{array}$ & $\%$ & $\begin{array}{c}\text { Frekue } \\
\text { nsi } \\
\text { Kesala } \\
\text { han }\end{array}$ & $\%$ & 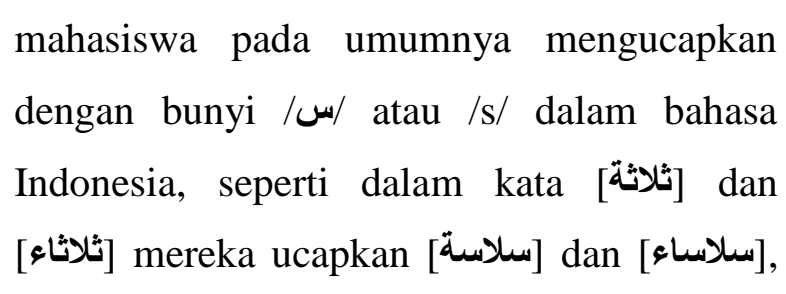 \\
\hline (1) & $\dot{H}$ & 176 & 9,7 & 108 & 5,9 & dan dalam kata [شكرا], [شهر], dan [شاطئ البحر] \\
\hline (2) & $\tau$ & 163 & 8,9 & 76 & 4,2 & mereka ucapkan [سكرا], سهر] dan [ ساطئ] \\
\hline (3) & $\dot{\tau}$ & 198 & 10 & 81 & 4,4 & 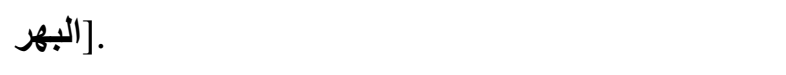 \\
\hline & & & 9 & & & Kemudian, dalam pengucapan bunyi \\
\hline (4) & j & 169 & 9,3 & 98 & 5,4 & / dan آ| mahasiswa cenderung \\
\hline (5) & 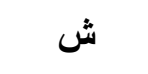 & 157 & 8,7 & 62 & 3,4 & mengucapkan dengan bunyi / / / atau /h/ \\
\hline (6) & ص & 137 & 7,6 & 52 & 2,9 & dalam bahasa Indonesia, seperti dalam kata \\
\hline (7) & 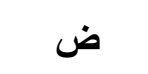 & 144 & 7,9 & 113 & 6,2 & [حالك]], [حيقة الحيوانات ] mereka \\
\hline$(8)$ & $b$ & 112 & 6,2 & 27 & 1,5 & ucapkan [هالك]], [البهر], dan [ هديقة الهيوانات], \\
\hline (9) & ظ & 104 & 5,7 & 51 & 2,8 & dan kata [خخير], [خمسة], dan [خلاص] mereka \\
\hline$(10)$ & $\varepsilon$ & 232 & $\begin{array}{c}12 \\
8\end{array}$ & 102 & 5,6 & $\begin{array}{l}\text { ucapkan [bi hoir], [homsah], dan [holas]. } \\
\text { Selanjutnya, dalam pengucapan bunyi }\end{array}$ \\
\hline$(11)$ & $\dot{\varepsilon}$ & 101 & 5,6 & 43 & 2,3 & / / mahasiswa cenderung mengucapkan \\
\hline$(12)$ & ق & 122 & 6,7 & 72 & 3,9 & dengan bunyi / $/$ / atau /a/ dan /ng/ dalam \\
\hline & $\begin{array}{l}\text { Juml } \\
\text { ah }\end{array}$ & 1825 & $\begin{array}{l}10 \\
0\end{array}$ & 885 & $\begin{array}{l}48, \\
5\end{array}$ & 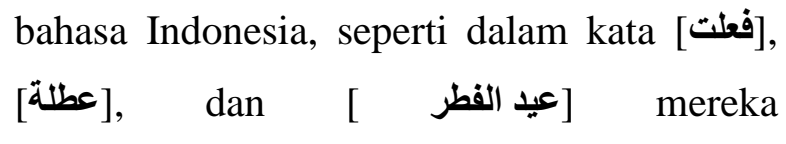 \\
\hline
\end{tabular}

Pada tabel 1 di atas tampak bahwa [utlah/ngutlah], dan [idul/ngidul fitri].

fonem /ض/ merupakan fonem yang paling sering terjadi kesalahan pengucapan dalam percakapan bahasa Arab mahasiswa dengan frekuensi kesalahan pengucapan 113 kali $(6,2 \%)$. Selanjutnya disusul oleh kesalahan pengucapan fonem / / / / / / 108 kali 102 kali (5,6\%), ذ/ 98 kali (5,4\%), / / 81 kali (4,4\%), / / 76 kali (4,2), 72 ka), /ظ/ k kali (3,4\%), 62 / 52 kali (2,9\%) 51 kali (2,8\%), , 43 kali (2,3\%), dan /ط/ 27 kali $(1,5 \%)$.

Dalam pengucapan bunyi / / dan /, 
Demikian pula dengan fonem |غ mahasiswa cenderung mengucapkan dengan fonem /g/ dalam bahasa Indonesia, seperti dalam kata [غذا] [بغا] mereka mengucapkannya dengan [godan] dan [bi goiri].

Lebih lanjut, dalam pengucapan bunyi /ض/, mahasiswa pada umumnya mengucapkan fonem tersebut dengan bunyi /د/ atau /d/ dalam bahasa Indonesia, seperti dalam kata [أيضا], [قضيت] dan mereka mengucapkannya dengan [aidon], [qodoita/qodoiti/qodoitu], dan [al-madiy].

Jika dilihat dari paparan data mengenai jenis-jenis kesalahan pengucapan bunyi bahasa Arab di atas, faktor yang menyebabkan terjadinya kesalahan tersebut dapat dikategorikan sebagai kesalahan antarbahasa (interlanguage errors), yaitu kesalahan yang disebabkan oleh interferensi bahasa ibu atau bahasa pertama (B1) si pelajar/mahasiswa terhadap bahasa kedua (B2) atau bahasa asing yang dipelajari.

Pengucapan fonem (bunyi) bahasa ibu atau bahasa pertama (B1) mahasiswa, dalam hal ini bahasa Indonesia atau bahasa daerahnya, memiliki pengaruh besar dalam pengucapan fonem (bunyi) bahasa Arab yang sedang dipelajari. Mengingat 12 macam fonem bahasa Arab:

$$
\text { /ع/ث/، /ح/، /خ/، /ذ/، /ش/، /ص/، اض/، /ط/، /ظ/، }
$$

tidak ada padanannya dalam fonem bahasa ibu atau bahasa pertama (B1) mahasiswa, maka mereka mengalami kesulitan untuk mengucapkan dua belas fonem bahasa Arab tersebut sesuai dengan makhraj-nya sebagaimana pengucapan penutur asli bahasa Arab.

Hal ini nampaknya sejalan dengan teori Analisis Kontrastif yang menyatakan bahwa kesalahan bahasa terjadi karena transfer negatif, yaitu penggunaan sistem bahasa ibu atau bahasa pertama (B1) dalam sistem bahasa kedua (B2) atau bahasa asing yang dipelajari, sementara kedua sistem bahasa tersebut berbeda. ${ }^{7}$ Selanjutnya, menurut teori Analisis Kontrastif, kesalahan bahasa itu dapat dihilangkan dengan cara menanamkan kebiasaan bahasa kedua atau asing yang dipelajari melalui latihan, pengulangan, dan penguatan (reinforcement). ${ }^{8}$

Hal ini berarti bahwa untuk menghilangkan kesalahan dalam pengucapan fonem bahasa Arab tersebut diperlukan latihan praktik pengucapan fonem bahasa Arab tersebut secara berulang-ulang disertai dengan penguatan (reinforcement). Latihan dimaksud bukan dalam bentuk latihan praktik pengucapan fonem bahasa Arab terpisah dari kontek kata dan kalimat, melainkan sebaliknya, mesti dalam bentuk latihan praktik pengucapan fonem bahasa Arab

\footnotetext{
${ }^{7}$ Henry Guntur Tarigan dan Djago Tarigan, Pengajaran Analisis., h. 23.

${ }^{8}$ Ibid.
} 
dalam konteks kata dan kalimat yang bermakna. Dengan begitu, mahasiswa diharapkan mampu mengucapkan fonem bahasa Arab tersebut sesuai dengan makhraj-nya.

\section{Kesalahan Morfologi (Sharaf)}

Dari hasil rekaman dan transkripsi hasil rekaman percakapan bahasa Arab mahasiswa Semester III Jurusan Pendidikan Bahasa Arab IAIN Metro Tahun Akademik 2017/2018 dalam perkuliahan Maharah al-Kalam 2, diperoleh data mengenai kesalahan morfologi (sharaf) sebagai berikut:

Tabel 2: Kesalahan Morfologi (Sharaf)

\begin{tabular}{|c|c|c|c|c|c|}
\hline $\begin{array}{l}\mathbf{N} \\
\text { o. }\end{array}$ & $\begin{array}{c}\text { Bent } \\
\text { uk } \\
\text { Kata }\end{array}$ & $\begin{array}{c}\text { Frekue } \\
\text { nsi } \\
\text { Pemaka } \\
\text { ian }\end{array}$ & $\%$ & $\begin{array}{c}\text { Frekue } \\
\text { nsi } \\
\text { Kesala } \\
\text { han }\end{array}$ & $\%$ \\
\hline$(1$ & الفعل & 321 & 89, & 14 & 3 \\
\hline ) & ي الماض & & 9 & & 9 \\
\hline (2 & الفعل & 36 & 10 & 5 & 1, \\
\hline ) & ع المضار & & 1 & & 4 \\
\hline & $\begin{array}{c}\text { Juml } \\
\text { ah }\end{array}$ & 357 & $\begin{array}{c}10 \\
0\end{array}$ & 19 & $\begin{array}{l}5, \\
3\end{array}$ \\
\hline
\end{tabular}

Pada tabel di atas tampak bahwa fi 'il madhiy merupakan bentuk kata bahasa Arab yang paling sering terjadi kesalahan dalam penerapan qawa'id sharfiyah dengan frekuensi kesalahan sebanyak 14 kali $(3,9 \%)$. Selanjutnya disusul oleh kesalahan penerapan kaidah fi'il mudhari' sebanyak 5 kali (1,4\%). Beberapa jenis kesalahan tashrif fi'il madhiy tersebut dapat dilihat pada tabel berikut:

Tabel 4: Jenis Kesalahan Tashrif Fi'il

\section{Madhiy}

\section{No Jenis Kesalahan Koreksi}

\section{Kesalahan}

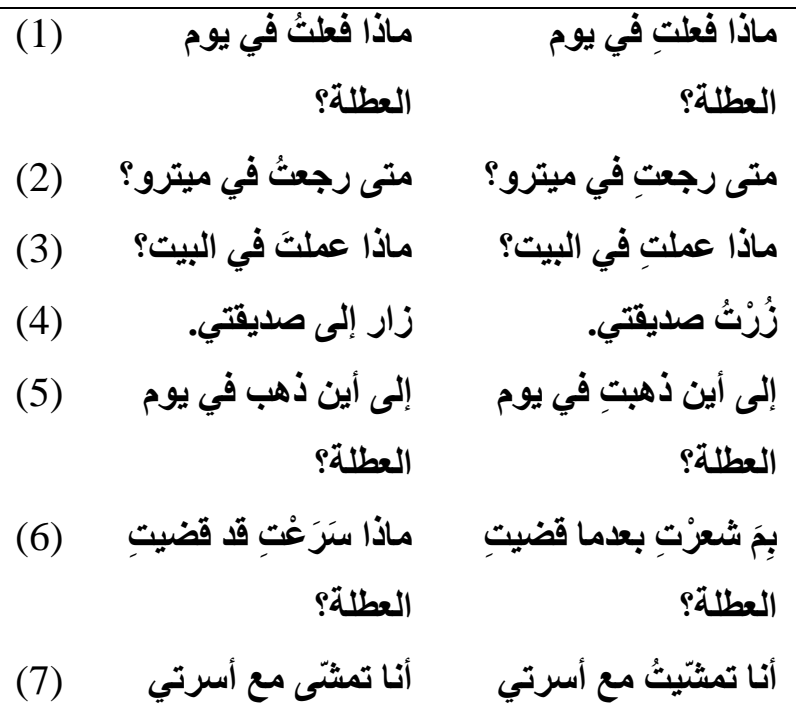

Sedangkan beberapa jenis kesalahan tashrif fi 'il mudhari' dapat dilihat pada tabel berikut:

Tabel 5: Jenis Kesalahan Tashrif Fi'il

\section{Mudhari'}

\begin{tabular}{|c|c|c|}
\hline No & Jenis Kesalahan & $\begin{array}{c}\text { Koreksi } \\
\text { Kesalahan }\end{array}$ \\
\hline (1) & أساعدتُ الو الديني. & أسـاعدُ و الايّ. \\
\hline (2) & أساعدين أمّي وأبي. & أسـاعد أمّي وأبي. \\
\hline (3) & لماذا أحزِن يا أختي؟ & لماذا تحزَنين يـا أختي؟ \\
\hline
\end{tabular}

Pada tabel 5 di atas tampak bahwa beberapa mahasiswa mengalami kesalahan dalam penerapan tashrif fi'il madhiy dan fi'il 
mudhari' untuk dhamir mukhathab (أنت) dhamir mutakallim (أنا).

Jika dilihat dari paparan data mengenai jenis-jenis kesalahan penerapan tashrif fi 'il madhiy dan mudhari' di atas, faktor yang menyebabkan terjadinya kesalahan tersebut dapat dikategorikan sebagai kesalahan intrabahasa (intralingual errors), yaitu kesalahan yang merefleksikan ciri-ciri umum kaidah yang dipelajari seperti kesalahan generalisasi, aplikasi yang tidak sempurna terhadap kaidah bahasa. ${ }^{9}$

Salah satu faktor yang menyebabkan terjadinya kesalahan intrabahasa (intralingual errors) ini adalah penerapan kaidah yang tidak sempurna (incomplete application of rules), yaitu kesalahan yang disebabkan oleh terjadinya strukturstruktur yang penyimpangannya menggambarkan taraf perkembangan kaidah-kaidah yang diperlukan untuk menghasilkan ucapan atau ujaran yang dapat diterima. ${ }^{10}$

Dalam kaitannya dengan kesalahan tashrif fi 'il madhiy dan mudhari' di atas, hal ini menunjukkan bahwa mahasiswa belum menguasai kaidah tashrif fi'il madhiy dan mudhari' dengan sempurna. Namun demikian, kesalahan tersebut dipandang hal yang wajar karena

9 Henry Guntur Tarigan dan Djago Tarigan, Pengajaran Analisis., h. 85.

10 Jack Fisiak [ed]. Contrastive Linguistics., h. 174. mahasiswa tersebut masih dalam taraf perkembangan dalam mempelajari dan menguasai kaidah tashrif fi'il madhiy dan mudhari'. Seiring dengan perjalanan waktu dan perkembangan mereka dalam belajar bahasa Arab disertai dengan praktik berbicara dalam bahasa Arab secara intensif, kesalahan tersebut biasanya akan hilang dengan sendirinya.

\section{Kesalahan Sintaksis (Nahwu)}

Dari hasil rekaman dan transkripsi hasil rekaman percakapan bahasa Arab mahasiswa Jurusan Pendidikan Bahasa Arab IAIN Metro Tahun Akademik 2017/2018 dalam perkuliahan Maharah al-Kalam 2, diperoleh data mengenai kesalahan sintaksis (nahwu) pada aspek al-muthabaqat (kesesuaian bentuk dan jenis kata dalam kalimat) sebagai berikut:

Tabel 3: Kesalahan Sintaksis

\begin{tabular}{|c|c|c|c|c|c|}
\hline $\begin{array}{l}\mathbf{N} \\
\text { o. }\end{array}$ & $\begin{array}{c}\text { Susunan } \\
\text { Kalimat/ } \\
\text { Frase }\end{array}$ & $\begin{array}{c}\text { Frekue } \\
\text { nsi } \\
\text { Pemak } \\
\text { aian }\end{array}$ & $\%$ & $\begin{array}{c}\text { Freku } \\
\text { ensi } \\
\text { Kesala } \\
\text { han }\end{array}$ & $\%$ \\
\hline$(1$ & مبتدأ - خبر & 10 & 2,5 & 4 & 1 \\
\hline ) & & & & & \\
\hline$(2$ & فعل - فاعل & 207 & 51 , & 0 & 0 \\
\hline ) & & & 75 & & \\
\hline$(3$ & منعوت - & 18 & 4,5 & 16 & 0 \\
\hline ) & نعت & & & & 4 \\
\hline$(4$ & مضاف - & 86 & 21 , & 68 & 17 \\
\hline ) & مضاف إليه & & 5 & & \\
\hline
\end{tabular}




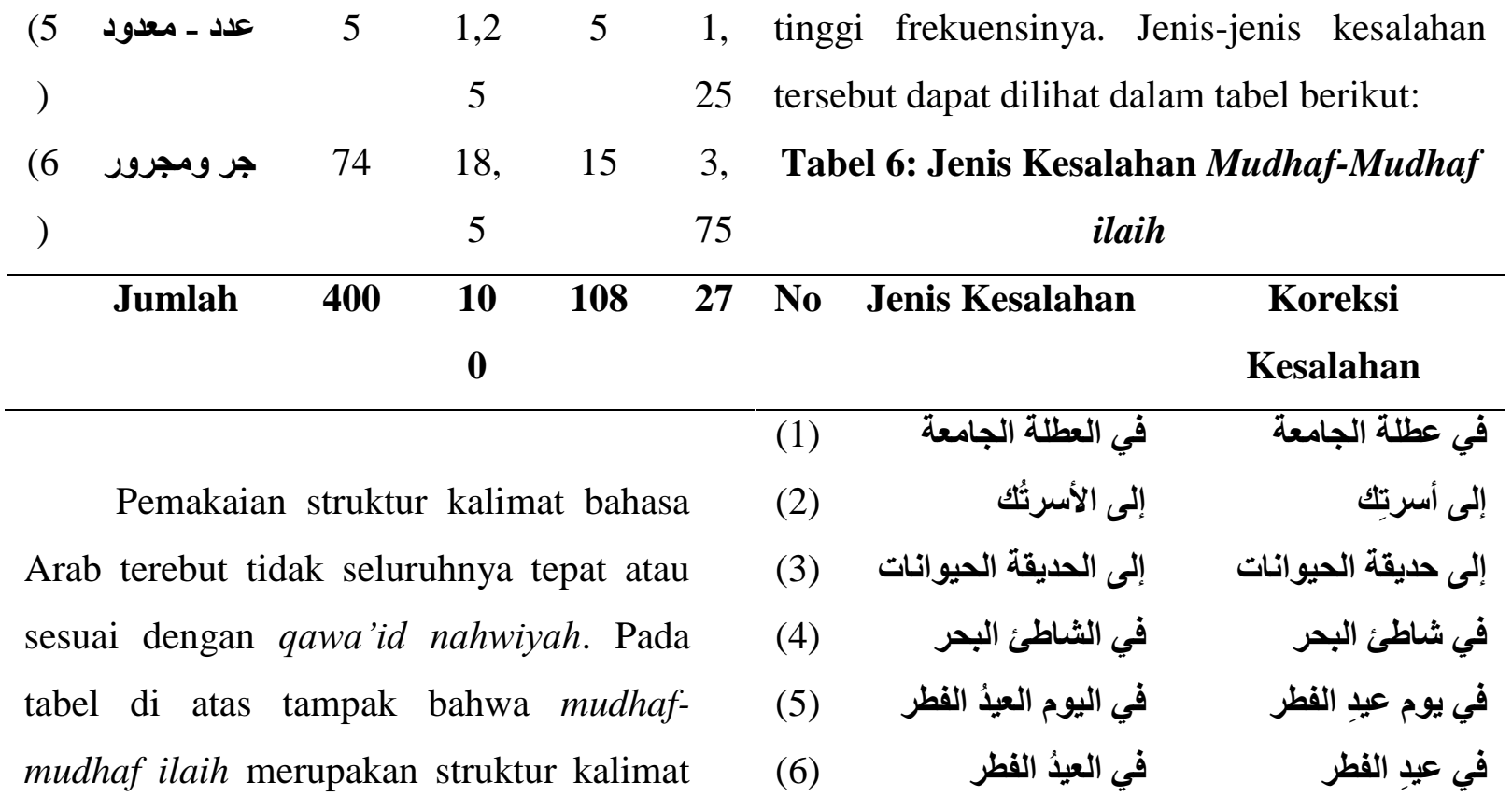

bahasa Arab yang paling sering terjadi kesalahan dalam penerapan qawa'id nahwiyah dengan frekuensi kesalahan sebanyak 68 kali (17\%). Kemudian disusul oleh na'at-man'ut 16 kali (4\%), jar-majrur 15 kali (3,75\%), 'adad-ma'dud 5 kali (1,25\%), dan mubtada'-khabar 4 kali $(1 \%)$.

Jenis kesalahan yang terjadi adalah ketidak-sesuaian antara mubtada dan khabar, sebagaimana dalam dialog antara dua orang mahasiswi berikut:

طالبة 1: أنا مسرور بلقائك.

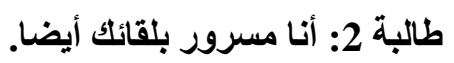

Seharusnya dialog tersebut dalam bentuk struktur jumlah ismiyah sebagai berikut:

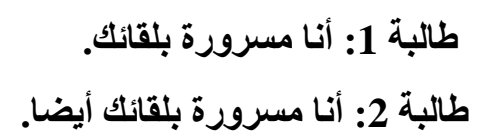

Selanjutnya, dalam penggunaan struktur mudhaf-mudhaf ilaih (tarkib idhafiy) terdapat kesalahan yang cukup
Tabel 6 di atas menunjukkan bahwa kesalahan yeng terjadi adalah penambahan morfem (ال) pada mudhaf yang seharusnya tidak ada. Meskipun kesalahan penerapan kaidah struktur mudhaf-mudhaf ilaih ini frekuensinya cukup tinggi, namun hal itu tidak berpengaruh terhadap perumahan makna yang dapat menyebabkan kesalahfahaman komunikasi. Meskipun terjadi kesalahan penerapan kaidah struktur mudhaf-mudhaf ilaih, namun proses komuikasi antara mahasiswa tetap berlangsung dengan baik.

Selanjutnya, dalam penggunaan struktur na'at-man 'ut (tarkib wasfiy) terdapat kesalahan dengan frekuensi yang sedikit. Jenis-jenis kesalahan tersebut dapat dilihat dalam tabel berikut:

Tabel 7: Jenis Kesalahan Na'at-man'ut No Jenis Kesalahan Koreksi 


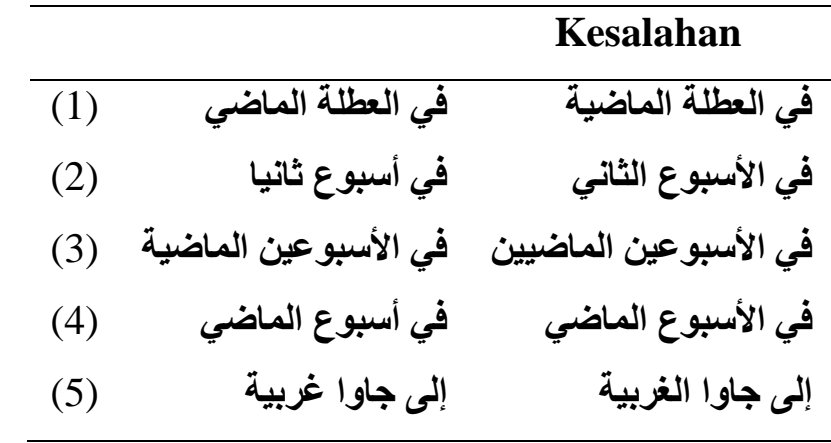

Tabel 7 di atas menunjukkan bahwa kesalahan yeng terjadi adalah ketidaksesuaian antara man'ut dan na'at baik dari segi mudzakkar dan mu'annats maupun segi 'adad. Sebagaimana halnya kesalahan mudhaf-mudhaf ilaih, kesalahan penerapan kaidah struktur na'at-man'ut ini juga tidak berpengaruh terhadap perumahan makna yang dapat menyebabkan kesalahfahaman komunikasi. Meskipun terjadi kesalahan penerapan kaidah struktur na'at-man'ut, namun proses komuikasi antara mahasiswa tetap berlangsung dengan baik.

Selanjutnya, dalam penggunaan struktur 'adad-ma'dud (tarkib 'adadiy) terdapat kesalahan dengan frekuensi yang sedikit. Jenis-jenis kesalahan tersebut dapat dilihat dalam tabel berikut:

Tabel 8: Jenis Kesalahan 'Adad-Ma'dud

\begin{tabular}{|c|c|c|}
\hline No & $\begin{array}{l}\text { Jenis } \\
\text { Kesalahan }\end{array}$ & $\begin{array}{c}\text { Koreksi } \\
\text { Kesalahan }\end{array}$ \\
\hline (1) & ثُلاث يوما & ثُلاثة أيّام \\
\hline (2) & ثُلاثة يوم & ثُلاثة أيّام \\
\hline (3) & خمسة يوما & خمسة أيّام \\
\hline
\end{tabular}

Tabel 8 di atas menunjukkan bahwa kesalahan yeng terjadi adalah ketidak-tepatan dalam penerapan kaidah 'adad-ma'dud. Sebagaimana halnya kesalahan mudhafmudhaf ilaih dan na'at-man'ut, kesalahan penerapan kaidah struktur 'adad-ma'dud ini juga tidak berpengaruh terhadap perumahan makna yang dapat menyebabkan kesalahfahaman komunikasi. Meskipun terjadi kesalahan penerapan kaidah struktur 'adad-ma'dud, namun proses komuikasi antara mahasiswa tetap berlangsung dengan baik.

Selanjutnya, dalam penggunaan struktur 'adad-ma'dud (tarkib 'adadiy) terdapat kesalahan dengan frekuensi yang sedikit. Jenis-jenis kesalahan tersebut dapat dilihat dalam tabel berikut:

Tabel 9: Jenis Kesalahan Jar-Majrur

No Jenis Kesalahan Koreksi

Kesalahan

\begin{tabular}{|c|c|c|}
\hline (1) & إلى بيتُ الأستاذ & إلى بيتِ الأستاذ \\
\hline (2) & في بيت صديقتُك & في بيت صديقتِكِ \\
\hline (3) & في عيدُ الفطر & في عيدِ الفطر \\
\hline (4) & في شهر صومُ رمضان & في شهر صوم رمضان \\
\hline (5) & إلى حديقةً الحيو انات & إلى حديقةٍة الحيوانات \\
\hline
\end{tabular}

Tabel 9 di atas menunjukkan bahwa kesalahan yeng terjadi adalah ketidak-tepatan dalam penerapan kaidah jar-majrur. Sebagaimana halnya kesalahan mudhafmudhaf ilaih dan na'at-man'ut, kesalahan penerapan kaidah struktur jar-majrur ini juga tidak berpengaruh terhadap perumahan 
makna yang dapat menyebabkan kesalahfahaman komunikasi. Meskipun terjadi kesalahan penerapan kaidah struktur jar-majrur, namun proses komuikasi antara mahasiswa tetap berlangsung dengan baik.

Jika dilihat dari paparan data mengenai jenis-jenis kesalahan sintaksis di atas, faktor yang menyebabkan terjadinya kesalahan tersebut dapat dikategorikan sebagai kesalahan intrabahasa (intralingual errors), yaitu kesalahan yang merefleksikan ciri-ciri umum kaidah yang dipelajari seperti kesalahan generalisasi, aplikasi yang tidak sempurna terhadap kaidah bahasa, dan kegagalan mempelajari kondisi-kondisi penerapan kaidah. ${ }^{11}$

Salah satu faktor yang menyebabkan terjadinya kesalahan intrabahasa (intralingual errors) ini adalah penerapan kaidah yang tidak sempurna (incomplete application of rules), yaitu kesalahan yang disebabkan oleh terjadinya strukturstruktur yang penyimpangannya menggambarkan taraf perkembangan kaidah-kaidah yang diperlukan untuk menghasilkan ucapan atau ujaran yang dapat diterima. ${ }^{12}$

Dalam kaitannya dengan kesalahan sintaksis di atas, hal ini menunjukkan

11 Henry Guntur Tarigan dan Djago Tarigan, Pengajaran Analisis., h. 85.

12 Jack Fisiak [ed.]. Contrastive Linguistics., h. 174. bahwa mahasiswa belum menguasai kaidah mubtada'-khabar, mudhaf-mudhaf ilaih, na'at-man'ut, 'adad-ma'dud, dan jar-majrur dengan sempurna. Namun demikian, kesalahan tersebut dipandang hal yang wajar karena mahasiswa tersebut masih dalam taraf perkembangan dalam mempelajari dan menguasai kaidah tashrif fi'il madhiy dan mudhari'. Seiring dengan perjalanan waktu dan perkembangan mereka dalam belajar bahasa Arab disertai dengan praktik berbicara dalam bahasa Arab secara intensif, kesalahan tersebut biasanya akan semakin berkurang bahkan hilang.

\section{Kesimpulan}

Dari hasil penelitian dan pembahasan di atas dapat disimpulkan bahwa kesalahan bahasa pada percakapan bahasa Arab mahasiswa Semester III Jurusan Pendidikan Bahasa Arab IAIN Metro Tahun Akademik 2017/2018 dapat diklasifikasikan dalam tiga jeni kesalahan bahasa, yaitu: (1) kesalahan pengucapan bunyi (fonem), (2) kesalahan morfologi (sharaf), dan (3) kesalahan sintaksis (nahwu).

Pada jenis kesalahan pengucapan bunyi (fonem), frekuensi tertinggi terjadi pada kesalahan pengucapan bunyi ض/ sebanyak 113 kali (6,2\%), bunyi /ث/ 108 kali (5,9\%), bunyi / / 102 kali (5,6\%), dan bunyi /ذ/ 98 kali $(5,4 \%)$. Pada jenis kesalahan morfologi (sharaf), frekuensi tertinggi terjadi pada kesalahan tashrif fi'il madhiy dengan 
frekuensi kesalahan sebanyak 14 kali (3,9\%). Selanjutnya disusul oleh kesalahan tashrif fi 'il mudhari' sebanyak 5 kali (1,4\%). Pada jenis kesalahan sintaksis (nahwu), frekuensi tertinggi terjadi pada kesalahan struktur mudhafmudhaf ilaih dengan frekuensi kesalahan sebanyak 68 kali (17\%), na'at-man'ut 16 kali (4\%), dan jar-majrur 15 kali (3,75\%).

Adapun faktor yang menyebabkan terjadinya kesalahan pengucapan fonem dapat dikategorikan sebagai kesalahan antarbahasa (interlanguage errors), yaitu kesalahan yang disebabkan oleh interferensi bahasa ibu atau bahasa pertama (B1) si pelajar/mahasiswa terhadap bahasa kedua (B2) atau bahasa asing yang dipelajari. Sedangkan faktor yang menyebabkan terjadinya kesalahan morfologi (sharaf) dan sintaksis (nahwu) dapat dikategorikan sebagai kesalahan intrabahasa (intralingual errors), yaitu kesalahan yang merefleksikan ciri-ciri umum kaidah yang dipelajari seperti kesalahan generalisasi, aplikasi yang tidak sempurna terhadap kaidah bahasa, dan kegagalan mempelajari kondisi-kondisi penerapan kaidah nahwu-sharaf.

\section{Daftar Pustaka}

Al-Ghalayaini, A.M. Jami' al-Durus al'Arabiyah. Beirut: al-Maktabah al'Ashriyah, 1987.
Chaudron, Craig. Second Language Classrooms: Research on Teaching and Learning. Cambridge: Cambridge University Press, 1988.

Corder, S.P. Error Analysis and Interlanguage. Oxford: Oxford University Press, 1986.Dulay, H. [et al], Language Two. Oxford: Oxford University Press, 1982.

Dahdah, Antoine. Mu'jam Qawa'id al-Lughah al-'Arabiyah fi Jadawil wa Lauhat, Beirut: Maktabah Lubnan, 1981.

Ellis, R. Understanding Second Language Acquisition. Oxford: Oxford University Press, 1987.

Fisiak, Jack [ed.], Contrastive Linguistics and Language Teacher. New York: Pergamon Press, 1985.

Mahsun, Metode Penelitian Bahasa: Tahapan Strategi, Metode, dan Tekniknya. Jakarta: RajaGrafindo Persada, 2005.

Nunan, Davic iesearch Methods in Language Learning. Cambridge: Cambridge University Press, 1992.

Olsson, M. A Study of Errors, Frequencies, Origin, and Effects. Goteborg Sweden: Pedagogiska Institutionen, 1974.

Richards, J. [ed.]. Error Analysis: Perspectives on Second Language Acquisition. London: Longman, 1985.

Syamsuddin dan V.S. Damaianti. Metode Penelitian Pendidikan Bahasa, Bandung: Remaja Rosdakarya, 2006.

Tarigan, H. G., dan Djago Tarigan. Pengajaran Analisis Kesalahan Bahasa. Bandung: Angkasa, 1990.

Tarigan, H. G. Prinsip-Prinsip Dasar Metode 
Riset Pengajaran dan Pembelajaran

Bahasa. Edisi Revisi. Bandung: Angkasa, 2009.

Thu'aimah, Rusydi Ahmad. Ta'lim al'Arabiyah li Ghair al-Nathiqin biha. Rabath: ISISCO, 1989.

Umam, Chotibul. Aspek-Aspek Fundamental dalam Mempelajari Bahasa Arab, Bandung: al-Ma'arif, 1980.

Wahab, Abdul. Butir-Butir Linguistik. Surabaya: Erlangga University Press, 1990. 